\title{
FORMING AND DISAPPEARANCE OF SMALL RETENTION SYSTEM IN THE POSTINDUSTRIAL AREA - CASE STUDY FROM THE CENTRAL SECTION OF THE KAMIONKA RIVER VALLEY (CENTRAL POLAND) SINCE THE 18TH CENTURY
}

DOI: https://doi.org/10.18509/AGB.2019.04

UDC: 556.34:[504.61:622(438)"17/20"

\author{
Tomasz Kalicki, Paweł Przepióra, Michał Aksamit, \\ Marcin Frączek, Edyta Kłusakiewicz, Paulina Grzeszczyk \\ Jan Kochanowski University in Kielce, Institute of Geography, \\ Department of Geomorphology, Geoarchaeology and Environmental Management, Poland \\ corresponding author: tomaszkalicki@ymail.com
}

\begin{abstract}
The Kamionka Valley is an old industrial area located in the northern part of the Świętokrzyskie Province. From the early Middle Ages was mined here iron ore and processed in forges located on the river. Many forges was operating also in Suchedniów located in middle section of the river. For over the last centuries, in this area the river have been occurred many anthropogenic changes related to human impact. Industry, based on mining and metallurgy, developed here as part of the Old Polish Industrial District and the Central Industrial District. Their activities contributed to numerous changes in the riverbed and the construction of water reservoirs creating system of small retention in Kamionka. Most changes on the river took place in time of high activity of the forges (from 18th to the first half of the 20th century). Changes in industrial activity reduce the number of ponds on the river led to an increased risk of flash floods, which perfectly illustrates the events taking place downstream of the Suchedniów reservoir dam (1974 and 2010).
\end{abstract}

Keywords: Holy Cross Mts., Kamionka river, human impact, flash floods, small retention, forges

\section{INTRODUCTION}

The Kamionka river valley is located in the northern part of the Świętokrzyskie Province. Iron ore was mined here from the early Middle Ages, which was processed in forges. Those forges was operating also in Suchedniów town located in middle section of the river. Kamionka is the right tributary of Kamienna river. The entire catchment area is located on the Suchedniów Plateau. Kamionka is a meandering river with a length about $17 \mathrm{~km}$ and an average slope $5 \%$ [1]. During the last centuries, in its middle section of the river there have been occurred many anthropogenic changes related to industrial activity. Industry, based on mining and metallurgy, developed here as part of the Old Polish Industrial District and then Central Industrial District. Suchedniów was established here as a small settlement. First historical data of it come from years 1224 [2] and from 1510 come first information about the forge operating on the river
[3]. Their activities contributed to numerous changes in the riverbed and the construction of water reservoirs creating system of small retention in Kamionka basin. At the turn of the $19^{\text {th }}$ and $20^{\text {th }}$ century, the forges on Kamionka river were abandoned. In their place was built water mills using old hydrotechnical infrastructure. To the half of the $20^{\text {th }}$ century numerous small ponds were drained and replaced with larger reservoirs for retention purposes.

The further expansion of the city contributed to regulating the riverbed which resulted in the disappearance of the flood plain on some sections of Kamionka river valley (just like downstream of the Suchedniów reservoir dam). Changes in the water cycle in the Kamionka river basin introduced by man led to the emergence of new catastrophic events on the river. 


\section{AIM OF THE STUDY AND METHODS}

The article focuses on the analysis of anthropogenic changes at Kamionka and their impact on the development of the Suchedniów area in recent centuries.

An analysis of archival materials (old topographical maps, Suchedniów situational plans, photographs) were compared with the results of the field observations of the studied area. There were used maps and archival materials from the $18^{\text {th }}$ century (some of information are from $16^{\text {th }}$ century) to the first half of the $20^{\text {th }}$ century. A large part of these materials comes from private collections of the people living in Suchedniów, as well as from the "Suchedniów Lexicon" [3]. The results of these studies have allowed the location of former hydrotechnical objects and their remnants on Kamionka river in this area. Also was made an analysis of modern hydrotechnical facilities in Suchedniow and their impact on the development of the city. In 2017 there was begin a works leading to deepening reservoir in the Suchedniów. In fact this moment was used to made extensive analysis of forms and sediments of this hydrotechnical object.

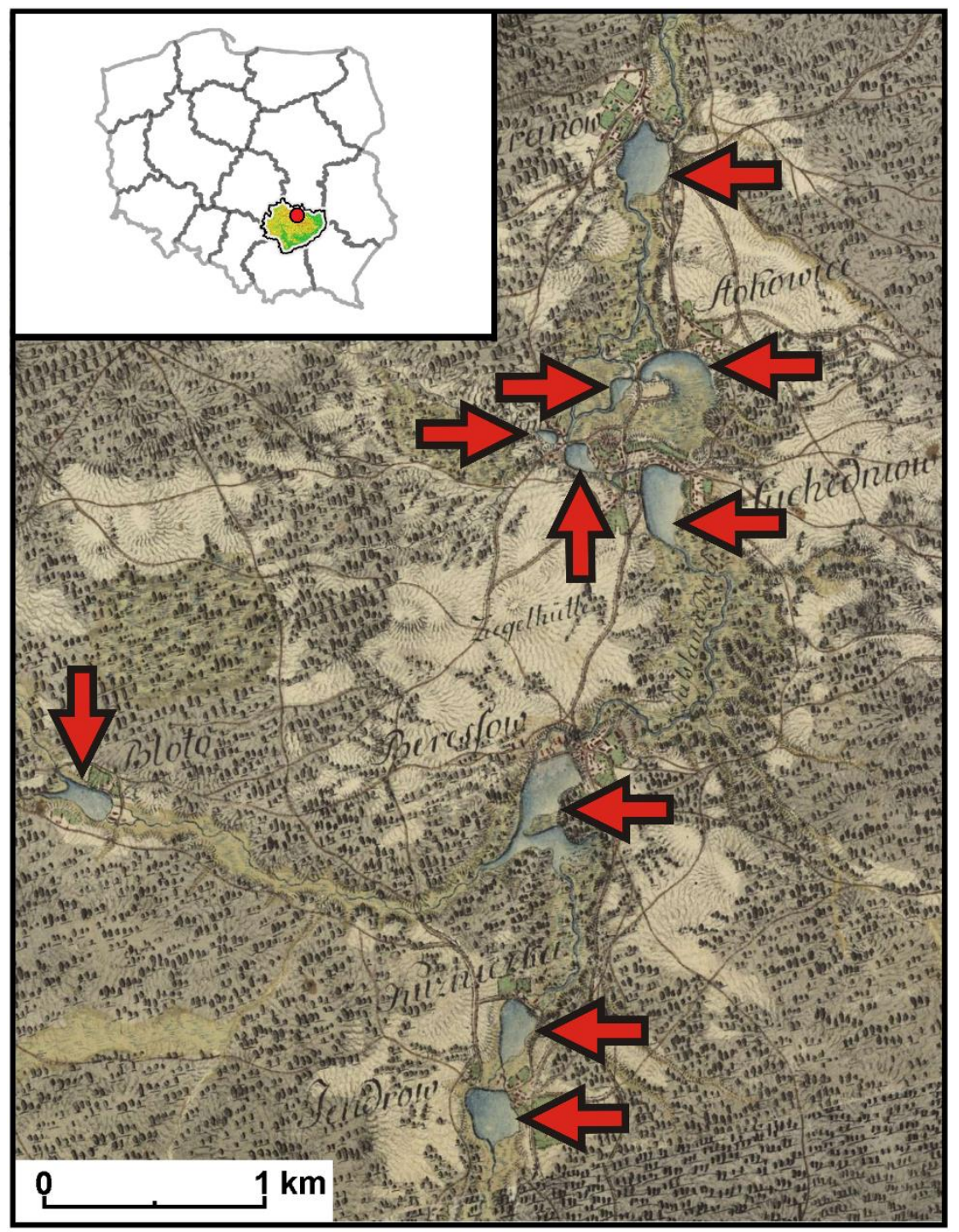

Figure 1. The research area with the location of former industrial and mill reservoirs on the archival map First Military Survey (1763-1787) - West Gallizien (1801-1804)

The presented results are a part of research on anthropogenic changes of forms and sediments in the Holy Cross Mountains valleys carried out in the Department of Geomorphology, Geoarcheology and Environmental Management of the Institute of Geography Jan Kochanowski University in Kielce in project BS 612480 "Funkcjonowanie środowiska geograficznego regionu świętokrzyskiego w warunkach zmian klimatu i narastającej antropopresji/Functioning of the geographical environment of the Świętokrzyskie region in the conditions of climate change and increasing of human impact" led by T. Kalicki. 


\section{HISTORICAL CHANGES}

Since Prehistoric times, and later in the Middle Ages, mining and metallurgy based on iron ore, which lies in the Triassic deposits, played an important role in the development of this area. To the west of the investigated area developed Prehistoric metallurgy using furnances known as bloomerys [4]. The first information of forges operating in the Suchedniów area came from the beginning of the $16^{\text {th }}$ century [3]. On Kamionka river at that time there were at least 7 forges [5]. Those forges use Kamionka river as proper source of energy. The processed iron ore came from mines located in nearby hills where are until today preserved many buried mining shafts. Local forests were also used as a source of charcoal, which were burned in the forges.

Suchedniów was a large mining and industrial center. The industrial and urban infrastructure was modernized by Stanisław Staszic [3]. Numerous embankments, channels, dams and ponds were built, which were an integral part of the infrastructure of the forges [5], [6]. The remains of the old infrastructure of those forges are still clearly visible in the center of Suchedniów (dry channel or ground shaft near the city park). Created ponds near of the old forges have not been preserved to this day, but they are clearly visible on topographic maps from the turn of the $18^{\text {th }}$ and $19^{\text {th }}$ century (First Military Survey 1763-1787 - West Gallizien 18011804) (Fig. 1). These reservoirs are also visible on many other sheets from later years, as well as on old photographs and town plans. Archival materials document the dynamics of changes taking place during the last centuries on Kamionka river. They show, among others formation and disappearance of the Suchedniów water reservoir [1](Fig. 2). In 1863 , as a result of insurgent actions, Suchedniów was completely burnt by the Muscovites. However, the hydrotechnical infrastructure of forges and mills was quickly rebuilt. The forges was used until the end of the $19^{\text {th }}$ century. Some of water mills was using remaining hydrotechnical infrastructure of old forges. To the half of the $20^{\text {th }}$ century water mills were no longer used in this area. This meant that up to the middle of the $20^{\text {th }}$ century, many smaller ponds in Kamionka disappeared. In modern times most of the mills have been destroyed (Baranów), while the rest have been restored (Berezów and Jędrów).

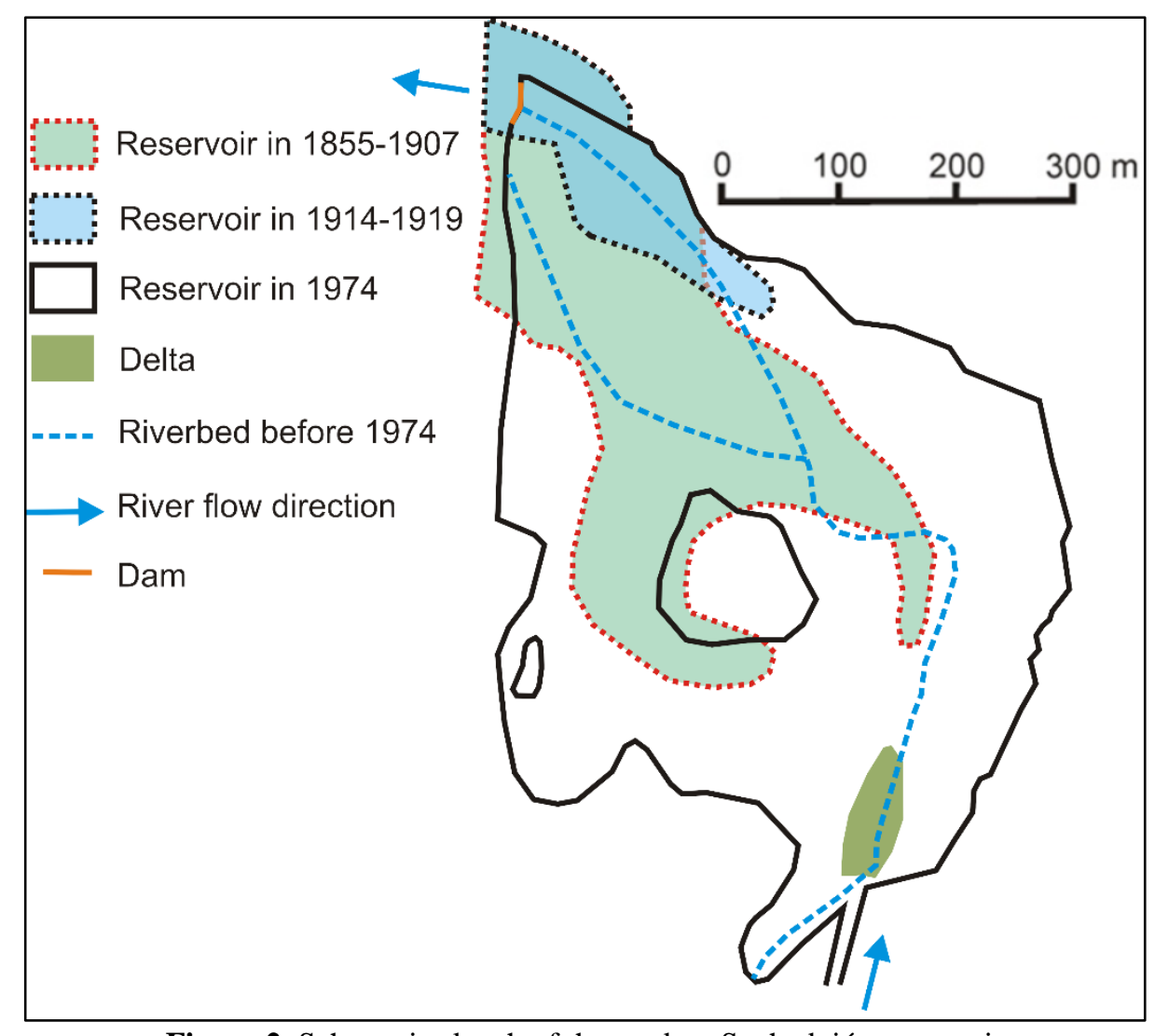

Figure 2. Schematic sketch of the modern Suchedniów reservoir with the boundaries of previous ponds and location of the former riverbed

\section{PRESENT-DAY CHANGES}

In the second half of the $20^{\text {th }}$ century, many water mills were abandoned or dismantled, and nearby ponds were drained. The traces of the former hydrotechnical infrastructure (shafts, channels, 
foundations of mills and forges) remained visible in the relief and landscape. Sometimes in the place of old forges was build later a larger factories (e.g. at Suchedniów). This action lead to the disappearance of small watercourses, just like Pstrążnica, small left-side tributary of Kamionka river [7], [8], [9]. North of Suchedniów, there is also a embankment of a $19^{\text {th }}$ century narrow-gauge railway, which was transported iron ore from the nearby mines and wood to the sawmill [3]. Currently, the track has been disassemble and the remaining embankment separates the flood plain into two parts.

In the places where forges and mills was working on the river forming anthropogenic anastomoses as a result of industrial activity in the Kamionka. In such sections the river flows simultaneously with a natural channel and at least one anthropogenic channel (e.g. at Baranów) [10]. These anastomoses also functioned in historical times, that is visible in archival maps from last centuries. This type of river bed development also occurs on many other rivers of the Old Polish Industrial District, e.g. on the Wierna Rzeka [11]. In the second half of $20^{\text {th }}$ century the small typical industrial ponds were abandoned for the benefit of larger retention and touristic reservoirs purposes, e.g. the reservoir built in 1974 at Suchedniów and at Rejów.

In 2005, the course of the river was changed near the campsite at the Sports and Recreation Center in Suchedniów. A several-hundred-meter-long channel was dug, which Kamionka flows into the reservoir, and the natural riverbed section has been buried. Present-day there is a small haven in the former estuary [1].

The current hydrotechnical infrastructure on Kamionka does not provide full retention possibilities. This led to the occurrence of sudden catastrophic events on the river, such as flash floods. They took place, for example in the Rejów reservoir in 1939 [12] as well in Suchedniów in 1974 [3], [13]. Shortly after completion of the construction works of the Suchedniów reservoir due to the overfilling of it, the shaft was broken near the dam. This lead to create a flood wave on the river downstream from the reservoir. The traces of these floods are visible on a short section of river downstream of the reservoir, where is accumulated the coarsest material (rocks, concrete fragments, sandstone pebbles) [14]. [15]. Recent research confirms the lowering of the retention functions of the reservoir due to its silting and shallowing. This was caused, among others, by construction of the S7 expressway, of which embankments were incised by Kamionka. This led to the include a large amount of material into river transport, which was accumulated in the reservoir at Suchedniów. The result of this process was the formation of a clear inland delta at the estuary of the river into the reservoir [16], [17]. Decreasing the flood potential of the Suchedniów reservoir lead to the occurrence of further catastrophic events [1].

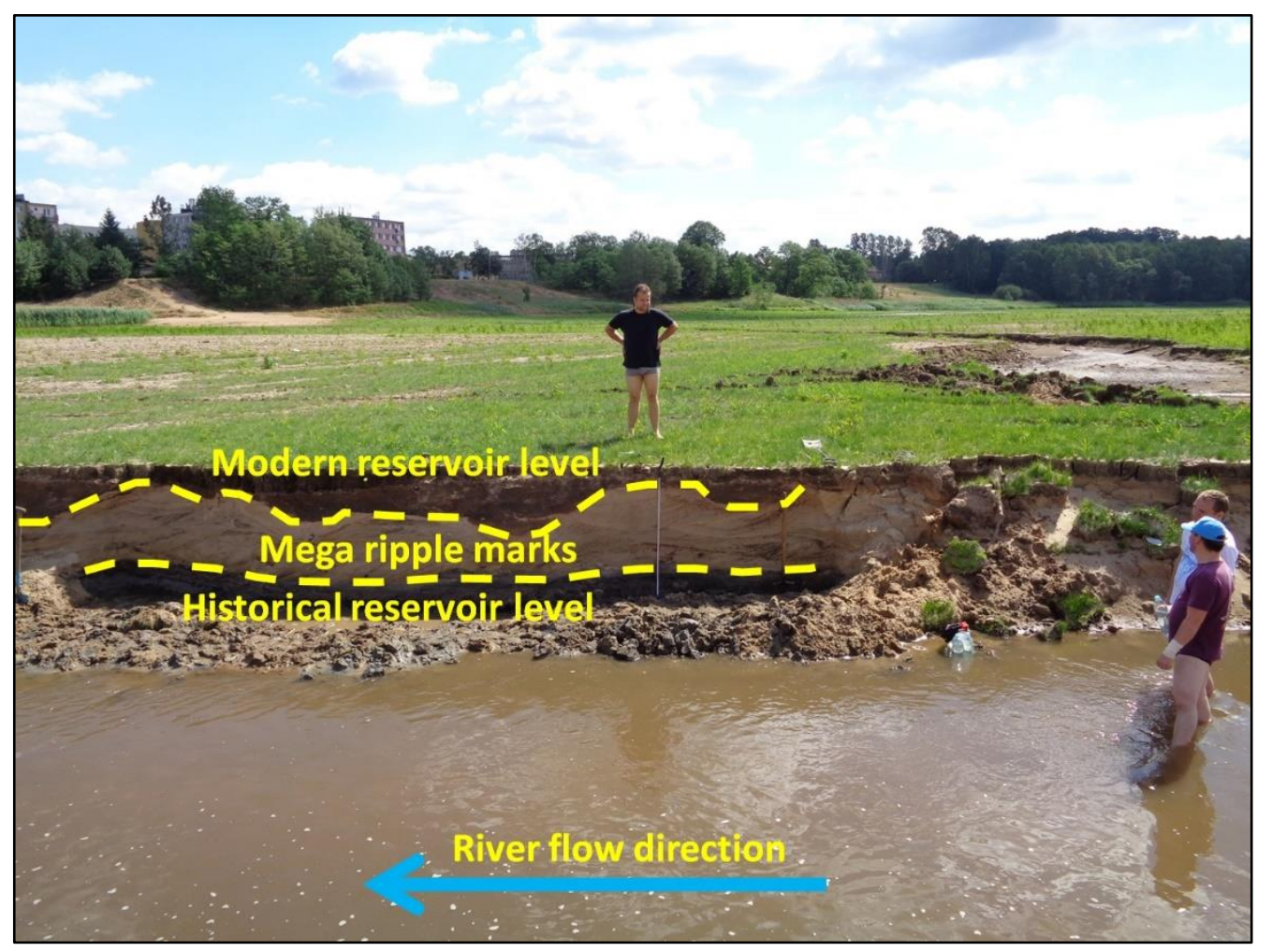

Figure 3. The channel made in the sediments of the modern Suchedniów reservoir with visible layers of sediments of the previous reservoir, covered with sandy mega ripple marks from the flood in 1974 (photo P. Przepióra in 2017) 
In 2017 started works lead to deepen the reservoir at Suchedniów. The aim of this work is to restore the reservoir's retention capabilities by sediments dredging from its bottom, removing deposits, creating new reservoir slopes and repairing the dam. The moment when reservoir become dry gave the opportunity to start research on the sediments and forms accumulated from the beginning of its

\section{CONCLUSIONS}

The presented area perfectly presents the high level of anthropogenic changes on the river caused by industrial activity. Most changes are visible near the Kamionka riverbed in the Suchedniów area. Mining and metallurgical activities within the Old Polish and Central Industrial Districts contributed to the creation of many water mill ponds on Kamionka river.

Most changes on the river took place from the 18th to the first half of the 20th century, when most metallurgical plants and water mills were active in here. Kamionka was regulated, especially in the middle section, as a result of the construction of many channels, reservoirs and a change in the direction of the river's flow. Human activity on the existence. During this work was discovered remains of the previous reservoir (probably from the beginning of the 20th century) as the distinct, dark layer of muds. This material was covered by $1.0-1.5$ $\mathrm{m}$ diameter, sandy mega ripple marks left by the flood caused by the breaking of the dam in 1974 . All those layers are covered with sediment deposits of the modern reservoir.

river contributed to the formation of anthropogenic anastomoses, functioning in historical times, and locally also in modern times.

Reducing the number of ponds on the river led to an increased risk of flash floods, which perfectly illustrates the events taking place downstream from the dam in Suchedniów reservoir (1974 and 2010). Present-day, various investments are being carried out in Suchedniów on Kamionka to improve the hydroelectric infrastructure possibilities, as well as their tourist assets. These investments also enabled the discover in the sediments the old ponds remains. These discoveries confirms the disappearance of small retention which appear on many cartographic materials from the last centuries.

\section{REFERENCES}

[1] Przepióra P. Naturalne i historyczne zmiany zlewni Kamionki (Płaskowyż Suchedniowski) w subatlantyku. (typescript of PhD thesis), UJK, Kielce, 2017.

[2] Piekosiński F. Kodeks Dyplomatyczny Małopolski [T. 1.], 1178-1386. Wydawnictwa Komisiyi Historycznej Akademii Umiejętności w Krakowie, 16, pp. 16-17, 1876.

[3] Piasta. S. Leksykon Suchedniowa. Towarzystwo Przyjaciół Suchedniowa, Kielce, 2012.

[4] Orzechowski Sz. Zaplecze osadnicze i podstawy surowcowe starożytnego hutnictwa świętokrzyskiego. Kieleckie Towarzystwo Naukowe, Kielce, 2007.

[5] Bielenin K. Starożytne górnictwo i hutnictwo żelaza w Górach Świętokrzyskich. Wydanie drugie, poszerzone i poprawione. Kieleckie Towarzystwo Naukowe, 1993.

[6] Przepióra P., Król G., Kalicki T. Anhtropogenic changes of Kamionka Valley based on cartographic and historical sources. Abstract book and field guide - Geoarcheology of river valleys, UJK, Kielce, pp. 108-109, 2013.

[7] Przepióra P., Kłusakiewicz E., Kalicki T. Changes in the water cycle in the Kamionka river catchment based on historical maps and materials. Sbornik abstrakt 21. Kvarter, Ustav geologickych ved PrF MU, Brno, pp. $41,2015$.

[8] Przepióra P. Natural and historical changes of the Kamionka catchment (Suchedniów Platau) in Subatlantic, Kalicki T., Frączek M. (ed.), Abstract Book, Fluvial Archieves Group Biennial Meeting "Evolution of river valleys in Central Europe", UJK, Kielce, pp. 64, 2016.

[9] Przepióra P. Anthropogenic changes of river course and catastrophic events, Kalicki T., Frączek M., Przepióra P. (ed.), Field Guide, Fluvial Archieves Group Biennial Meeting "Evolution of river valleys in Central Europe", UJK, Kielce, pp. 52-55, 2016.

[10] Przepióra P., Kalicki T., Kłusakiewicz E, Chrabąszcz M. Natural and anthropogenic anastomosing river pattern in Holy Cross Mountains region. Sbornik abstrakt 22. Kvarter, Ustav geologickych ved PrF MU a Ceska geologicka spolecost, Brno, pp. 31, 2016.

[11] Chrabąszcz M., Kalicki T., Frączek M., Przepióra P. Anthropogenic river pattern and sediments: case study from Wierna River valley (Holy Cross Mountains, Poland). Hajnalová M., Pažinová N. B., Šimunková K. (ed.), Kniha Abstraktov, 13. Konferencia Environmentálnej Archeológie, „Človek a krajina ...“, Katedra archeológie FF UKF v Nitre, Slovenská republika, pp. 35, 2017.

[12] Suligowski R. Maksymalny wiarygodny opad na Wyżynie Kieleckiej, Wyd. UJK, Kielce, 230 pp., 2013.

[13] Gałczyńska-Szymczyk K. 55 lat miasta Suchedniów - Wydarzenia, miejsca, spotkania, Wyd. Urząd Miasta i Gminy w Suchedniowie, 151 pp., 2017. 
[14] Przepióra P., Frączek. M., Król G. Wpływ działalności przemysłowej na wybrane komponenty środowiska przyrodniczego w okolicach Suchedniowa, Streszczenia abstraktów, Ogólnopolska Konferencja Naukowa „Edukacja-Zdrowie-Środowisko”, UJK, Kielce, pp. 38, 2016.

[15] Przepióra P., Frączek M., Król G., Kalicki T. Wpływ działalności przemysłowej na wybrane komponenty środowiska przyrodniczego w okolicach Suchedniowa. Chmielewski J., Żeber-Dzikowska I., Gworek B. (red.), Człowiek a środowisko - wzajemne oddziaływanie, Instytut Ochrony Środowiska - Państwowy Instytut Badawczy, Warszawa, pp. 59-67, 2016.

[16] Bąk Ł., Górski J., Szeląg B. Wpływ kaskady zbiorników małej retencji Suchedniów i Rejów na redukcję fali wezbraniowej na rzece Kamionka, Acta Sci. Pol., Formatio Circumiectus 11, 1, pp. 13-22, 2012.

[17] Górski J., Bąk Ł., Szeląg B. Wpływ budowy trasy ekspresowej S7 na odcinku Skarżysko-Kamienna - Występa na redukcję pojemności zbiornika Suchedniów na rzece Kamionka. Acta Sci. Pol., Formatio Circumiectus 11, 1, pp. 23-36, 2012. 